\title{
Adoption of forage technologies
}

JOHN CARADUS ${ }^{1}$, SIMON LOVATT ${ }^{2}$ and BRUCE BELGRAVE ${ }^{1}$ ${ }^{1}$ Grasslanz Technology Ltd, PB 11008, Palmerston North. ${ }^{2}$ AgResearch Ltd, PB 3123, Hamilton john.caradus@grasslanz.com

\begin{abstract}
Pastoral farmers seek to continue to increase on-farm productivity, and to do this they need new forage options that they can adopt into their current management strategies. Four case studies show that New Zealand farmers have rapidly adopted new technologies that include forage herbs, white clovers with improved stolon growing point densities, and novel endophyte technologies. The less disruptive these technologies are to accepted farmer management strategies the greater the likelihood of adoption.
\end{abstract}

Keywords: Forage technologies, adoption, chicory, white clover, endophytes

\section{Introduction}

In 1918, Leonard Cockayne stated that "the yield of meat or butterfat per acre is primarily a matter of the plant covering of the farm" (Cockayne 1918). This is still true today, and yet it is acknowledged that rate of pasture renewal may be lower than is optimal for economic growth in the pastoral sector.

New Zealand farmers are arguably the best in the world at adopting new pastoral technologies, which has enabled them to stay in the top rank of efficient food producers. In 1942, Hamilton observed that "a major factor in the success of the New Zealand dairy industry has been the readiness with which technological advances have been incorporated into farming practice, often enough under the stress of falling prices and the necessity to vindicate land values resulting from excessive optimism in periods of rising prices" (Hamilton 1942). There is a body of literature analysing why farmers do and do not adopt technologies on-farm (Rogers et al. 1988; Davis 1989; Feder \& Umali 1993; Sunding \& Zilberman 2001; Rogers 2003; Flett et al. 2004; Massey et al. 2004; Alvarez \& Nuthall 2006). These can be summarised as:

- The technology fails to address the real problem

- The technology does not fit easily with farmer patterns of work and the existing production system

- Requirement for inputs (data) that are not familiar or not available

- Complexity, i.e., the perception that learning and using a particular technology will be difficult; or the inability to trial the technology without an irreversible and/or large commitment

- An unclear cost-benefit relationship

However, in general, New Zealand farmers have been rapid adopters of new forage technologies, such as the herb chicory, and novel endophytes that have been shown to improve perennial ryegrass persistence and reduced animal health problems. Plant breeders have also attempted to achieve the compromise of high production and good persistence in important species such as white clover. This paper attempts to show the importance of these developments, and how willing farmers have been to adopt them into their farming systems. This paper will show that some pasture based technologies are adopted and used by farmers, sometimes rapidly but they all eventually succumb to new options and follow the normal bell shaped sales/ marketing curve. In the process they generate increased income for the industry.

\section{Chicory use in New Zealand}

Although chicory originated in southern Europe, it was in New Zealand that chicory was first widely used as forage (Li \& Kemp 2005). Chicory has developed from a herb that was not used in New Zealand forage systems 28 years ago to where it is now often a key component of high performance pasture and crop mixes for sheep, beef, dairy, and deer operations. In a dry environment, cows can produce up to $90 \%$ more milk when fed on chicory-containing pasture relative to perennial ryegrass (Chapman et al. 2008). Reasons for this improved milk production include:

- high protein levels (up to $26 \%$ crude protein, which may improve protein supply to dairy cows),

- high digestibility and rapid passage through the rumen, allowing high daily intake (Burke et al. 2000).

Chicory quality does not deteriorate as much over summer as can ryegrass quality, so there can be large quality differences between the two species in late summer and autumn. With good summer moisture, chicory can produce over $20000 \mathrm{~kg}$ dry matter (DM)/ ha/year, and have daily growth rates of 80 to $100 \mathrm{~kg}$ $\mathrm{DM} /$ ha/day in summer/autumn. 


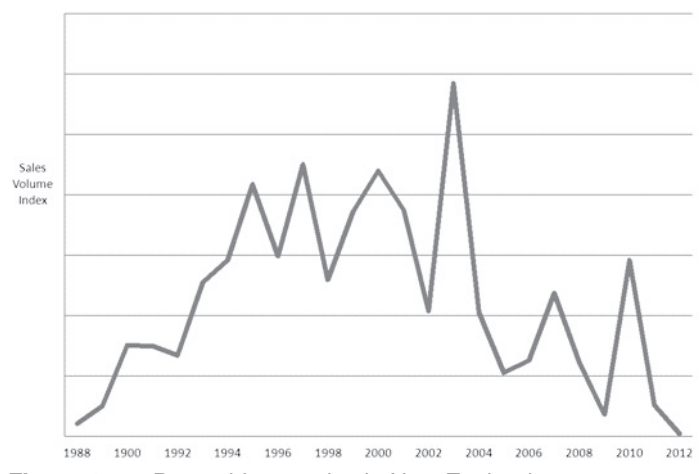

Figure 1 Puna chicory sales in New Zealand

Puna chicory, bred by AgResearch, was the first proprietary forage herb commercialised in New Zealand (Rumball 1986). By the early 1990s, between 8000 and 10000 ha of 'Grasslands Puna' chicory was sown annually in New Zealand (Moloney \& Milne 1993). The more modern cultivars, 'Grasslands Puna II' and 'Grasslands Choice', were bred from Puna (Rumball et al. 2003) and began to take over from Puna from 2003 onwards (Figure 1). However the proprietary chicory market in total has developed into a 250-300 tonne/year business worth $\$ 1700000$ (volume $\times$ wholesale seed value) to the New Zealand seed industry. This compares to traditional forage species tall fescue $\$ 600000$; white clover \$2 900 000; cocksfoot $\$ 200000$; red clover $\$ 860$ 000; and lucerne $\$ 330000$, again based on the calculation of volume of seed sold multiplied by the wholesale seed dollar value.

Based on the higher quality of chicory dry matter compared with typical ryegrass/clover pastures, and the reported yield of milk from chicory (Waugh et al. 1998), this herb species is now considered a crucial component of pastures providing high quality summer-autumn feed. The decline in Puna sowing from the early 2000 s onwards was due to the increase in sowing other chicory cultivars, suggesting that the total value of chicory to the New Zealand pastoral sector has not declined.

Chicory is now used in many temperate areas of the world as a pasture forage, including the USA (Ball 1997), Australia and South America.

\section{Breaking the stolon density by leaf size relationship in white clover}

In white clover, yield and persistence were often negatively associated because leaf size and upright habit contribute to yield potential while stolon growing point density contributes to persistence. In general, largeleaved white clover genotypes have lower growing point densities than small-leaved, less-productive genotypes. In a world first, the cultivar 'Grasslands Sustain' was developed to increase stolon growing point density (and

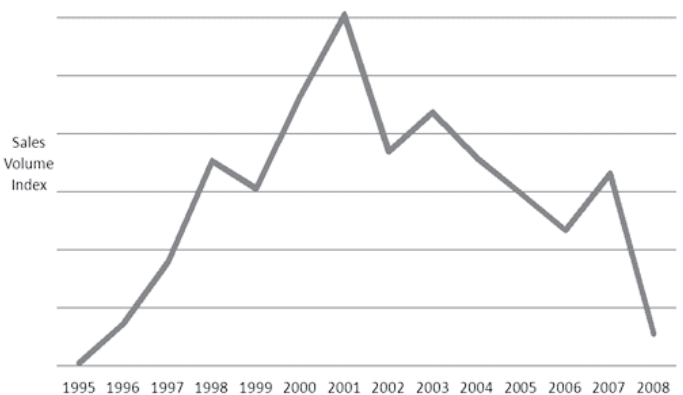

Figure 2 Volume of 'Grasslands Sustain' white clover seed sold to farmers in New Zealand

hence persistence) while maintaining a medium-large leaf size (Caradus et al. 1996a). This increased stolon growing point density resulted from a high proportion of stolon nodes producing branch stolons, which themselves rapidly produced nodes.

Lee et al. (1994) used cluster analysis to identify white clover populations that were both high yielding and persistent, and found 'Grasslands Sustain' and 'Grasslands Prestige' were the best among 24 populations evaluated. Both of these cultivars were bred for higher stolon growing point densities without reducing the respective leaf size of the base population from which they were selected (Caradus et al. 1996b). Improved persistence was achieved through higher nodal populations while maintaining the greater yield potential of larger leaf sizes. 'Grasslands Sustain' became the market-leading white clover cultivar in New Zealand in the late 1990s and early 2000s (Figure 2). It was eventually superseded by newer cultivars that provided improved yields but which are based on the same plant model - high stolon growing point densities for a particular leaf size category.

\section{AR1 endophyte}

Perennial ryegrass uses a symbiosis with an endophytic fungus (endophyte) that grows within the plant to protect itself from some insect pests. Unfortunately, in some endophyte strains the toxins produced to do this can cause animal health problems and reduce the amount of meat or milk produced by grazing animals (Thom et al. 2012). AgResearch scientists have discovered considerable variation in the alkaloid profile of endophyte strains (Tapper \& Latch 1999).

AR1 was the second novel endophyte commercialised in New Zealand in 2001. The first was Endosafe, commercialised in 1992 and then withdrawn in one cultivar due to its production of ergovaline, but continued in another where the host plant cultivar moderated the ergovaline expression. AR1 was released to provide 


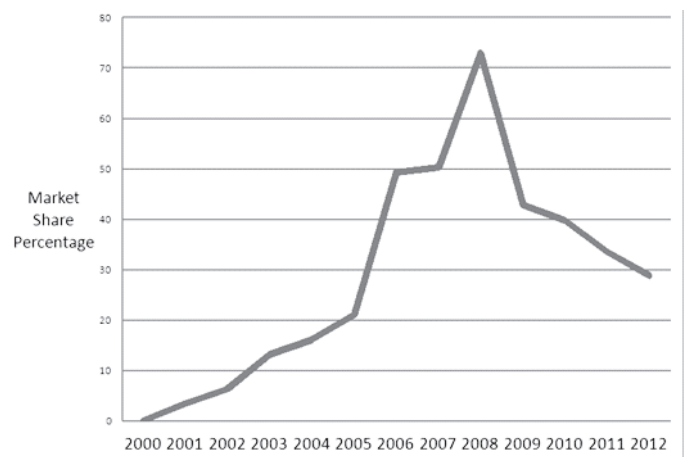

Figure 3 Uptake of AR1 endophyte ryegrasses by New Zealand farmers

an endophyte that provided resistance to Argentine stem weevil but did not cause ryegrass staggers (which results from the presence of lolitrem B (Fletcher 2004)) or heat stress (which results from the presence of ergovaline (Fletcher 2004)). Trials with sheep showed a $22 \%$ increase in returns to farmers through using AR1 over standard endophyte (Fletcher 1999).

It was a non-exclusive release and had a rapid uptake in New Zealand. AR1 is now licensed into 31 cultivars through 10 companies, exported to Australia and Chile, and is being evaluated in USA, Europe, Uruguay and Argentina.

Uptake by New Zealand farmers since AR1's full commercial release in 2003 has been extraordinary, such that, by 2008 , AR1 was used in $70 \%$ of the proprietary perennial ryegrass seed sold. After 2008, the AR37 and NEA2 endophytes entered the market. These provided a greater resistance to insect pests and AR1's share declined. AR1 now holds close to a 30\% share of the proprietary perennial ryegrass endophytic seed sold.

\section{AR37 endophyte}

The endophyte strain AR37 was identified along with a number of other endophyte strains during the 1980s and early 1990s. Subsequent research found that AR37 did not produce the alkaloid compounds lolitrem, peramine or ergovaline, but it did produce a unique indole diterpene-like compounds called epoxyjanthitrems (Fletcher 2004). Epoxy-janthitrems were found to confer a wide range of tolerance to insect pests, including Argentine stem weevil, black beetle, root aphid, pasture mealy bug and porina (Popay \& Bonos 2004). AR37 is also more persistent and higher yielding at critical times of the year (Hume \& Popay 2004). AR37 has also been noted to have increased ryegrass tiller numbers in trials before black beetle attack, which may also help explain better agronomic performance (Hume \& Ryan 2007). Cumulative root growth and increased root dry weight of AR37 relative to AR1, Nil, and wild type endophyte also helps explain better agronomic performance where there is insect pressure (Popay 2004).

The overall cost to a farmer of re-grassing a dairy farm has been estimated at \$1559/ha, including herbicide and application, cultivation, grass and clover seed, fertiliser, drilling and replacement supplementary feed while the pasture is out of production for 9 weeks (PRCT 2013, p.8). The Pasture Renewal Charitable Trust estimated that regrassing would typically increase dairy production by $250 \mathrm{~kg} / \mathrm{ha}$ (PRCT 2013, p.8), at a cost of $\$ 1559 /$ ha in the first year. If AR37 was responsible for $84 \mathrm{~kg} \mathrm{MS} / \mathrm{ha}$ out of that $250 \mathrm{~kg} \mathrm{MS} / \mathrm{ha}$ total, it would be appropriate to attribute that fraction $(33.6 \%)$ of the regrassing cost to AR37 (with the rest being attributed to the modern ryegrass cultivar that would carry the AR37). The same calculation assumed that $10 \%$ of the added value of the new grass would be lost each year after the first (PRCT 2013, p.8), so that assumption has also been made for AR37.

According to LIC \& DairyNZ (2012), the effective area of dairy farms from the central plateau northwards was about 715000 ha. Conservatively assuming a regrassing rate of $3 \%$ would suggest that about 21500 ha were re-grassed each year. For the purposes of this calculation, we assumed that all new re-grassing in this region from 2007 onwards used AR37 endophyte. While this was likely to overstate the amount of dairy farm area in the northern North Island that was regrassed with AR37 (especially in the first few years of AR37 availability), it ignored the sheep \& beef farm land in those regions that was regrassed with AR37 and it ignored any dairy, sheep and beef farm land in other regions that was regrassed with AR37.

On that basis, the cumulative area regrassed with AR37 could be estimated at about 130000 ha, now producing an additional 8.4 million $\mathrm{kg}$ MS each year, with a cumulative value to date to dairy farmers, net of the regrassing costs attributed to AR37, of $\$ 125$ million.

In trials at AgResearch's Lincoln campus, growth during the summer and autumn for hogget/lambs on pure ryegrass pasture averaged $29 \mathrm{~g}$ /day (assumes same growth rate in summer and autumn) for the standard endophyte, $74 \mathrm{~g}$ /day AR1 and $93 \mathrm{~g}$ /day for AR37 (Fletcher \& Sutherland 2009).

In early 2008, trials were undertaken to determine whether the measured increases in dry matter production through using AR37 were being converted into additional milksolids (MS) or meat. Trials by industry research organisation DairyNZ have shown total MS production over three consecutive lactations was not affected by endophyte treatment - AR1, AR37 or standard endophyte (Thom et al. 2012). AgResearch and DairyNZ scientists identified that, 
even if AR37 did seem to produce the same level of milksolids from the same pasture yield compared with AR1, there was evidence that AR37 would persist and yield more dry matter than AR1 over the medium term (AgResearch 2008). Therefore, where persistence of AR1 ryegrass was a problem, sowing AR37 ryegrass was recommended as the best option in areas where pasture pest pressure was high.

Since its first release in 2006, AR37 has been included in 11 ryegrass cultivars and its uptake has been very strong. AR37 had a predominant role in re-grassing of dairy pastures from the central plateau of the North Island northwards from 2007 to 2013.

\section{Conclusion}

New Zealand grassland farmers have embraced many new technologies developed by the research community which have targeted either high quality feed and/or pasture persistence. Some technologies that did not perhaps meet these needs have made less of an impact. These include proprietary cultivars of prairie grass, tall fescue, and lucerne. In each case these species provided high yield opportunities in certain environments but required different management options from those typically used for their benefits to be realised. Disruption to standard management practices will only be accepted if the potential benefits are significant.

\section{REFERENCES}

AgResearch 2008. Clarification on milksolids production from AR37. http://www.scoop.co.nz/ stories/SC0803/S00055.htm.

Alvarez, J.; Nuthall, P. 2006. Adoption of computer based information systems. The case of dairy farmers in Canterbury, NZ, and Florida, Uruguay. Computers and Electronics in Agriculture 50: 48-60

Ball, D. 1997. Forage Chicory. Alabama Cooperative Extension Service. Auburn University, AL. http:// www.aces.edu/department/forages/forchic.ht

Burke, J.L.; Waghorn, G.; Brookes, I.M.; Attwood, G.T.; Kolver, E.S. 2000. Formulating total mixed rations from forages - defining the digestion kinetics of contrasting species. Proceedings of the New Zealand Society of Animal Production 6: 9-14.

Caradus, J.R.; Clifford, P.T.P.; Chapman, D.F.; Cousins, G.R.; Williams, W.M.; Miller, J.E. 1996a. Breeding and description of Grasslands Sustain, a medium-large leaved white clover (Trifolium repens L.) cultivar. New Zealand Journal Agricultural Research 40: 1-7.

Caradus, J.R.; Woodfield, D.R.; Stewart, A.V. 1996b. Overview and vision for white clover. Grassland Research and Practice Series. 6: 1-6.
Chapman, D.F.; Tharmaraj, J.; Nie, Z.N. 2008. Milkproduction potential of different sward types in a temperate southern Australian environment, Grass and Forage Science, 63:221-233.

Cockayne, L. 1918 The importance of plant ecology with regard to agriculture. New Zealand Journal of Science \& Technology 1:70-74.

Davis, F.D. 1989. Perceived usefulness, perceived ease of use, and user acceptance of information technology. MIS Quarterly 13: 319-339

Feder, G.; Umali, D. L. 1993. The adoption of agricultural innovations: a review, Technological. Forecasting and Social Change 43: 215-239. http:// dx.doi.org/10.1016/0040-1625(93)90053-A

Fletcher, L.R. 1999. "Non-toxic" endophytes in ryegrass and their effect on livestock health and production. Grassland Research and Practice Series 7: 133-139.

Fletcher, L.R. 2004, Managing ryegrass-endophyte toxicosis 229- 241. In: R. Kallenbach et al (ed) Proceedings of the 5th International Symposium on Neotyphodium/Grass Interactions, Fayetteville, AR USA 23-26 May, 2004

Fletcher, L.R.; Sutherland, B.L. 2009. Sheep responses to grazing ryegrass with AR37 endophyte. Proceedings of New Zealand Grasslands Association. 71: 127-32

Flett, R.; Alpass, F.; Humphries, S.; Massey, C.; Morriss, S.; Long, N. 2004. The technology acceptance model and use of technology in New Zealand dairy farming. Agricultural Systems 80: 199-211.

Hamilton, W.M. 1942. A survey of the dairy industry in New Zealand. II. Technological advances in production. New Zealand Journal of Science \& Technology 24: (1A): 1A-35A

Hume, D.E.; Popay, A.J. 2004. Effect of a novel endophyte on the productivity of perennial ryegrass (Lolium perenne) in New Zealand. Proceedings of the 5th International Symposium on Neotyphodium/ Grass Interactions, Fayetteville, Arkansas. Poster 313

Hume, D.E.; Ryan, D.L. 2007. Agronomic performance of AR37-infected ryegrass in Northern New Zealand. Proceedings of New Zealand Grassland Association, 69: 201-205

Li, G.; Kemp, P.D. 2005. Forage chicory (Cichorium intybus L.): A review of its agronomy and animal production. Advances in Agronomy 88: 187-222.

LIC and DairyNZ. 2012. Dairy Statistics 2011/12. Hamilton, New Zealand, LIC.

Lee, C.K.; Eagles, H.A.; Caradus, J.R.; Reed, K.F.M. 1994. Investigation of yield and persistence of white clover using cluster analyses. Euphytica 72: 219-224.

Massey, C.; Morriss, S.; Alpass, F.; Flett, R. 2004. A framework for building technological learning: Evidence from the New Zealand dairy industry. Journal of Extension 42: 3 
Moloney, S.C.; Milne, G.D. 1993. Establishment and management of Grasslands Puna chicory used as a specialist, high quality forage herb. Proceedings of the New Zealand Grassland Association 55: 113-118

Popay, A.J. 2004. Aspects of the root ecology of Neotyphodium endophyte in Lolium perenne. Unpublished $\mathrm{PhD}$ thesis. University of Waikato, Hamilton, New Zealand.

Popay, A.J.; Bonos, S.A. 2004. Biotic responses in endophytic grasses. pp. 163-174. In: Proceedings of the 5th International Symposium on Neotyphodium/ Grass Interactions, Fayetteville, Arkansas.

PRCT (2013) Turn All Your Paddocks into High Producing Pasture, Pasture Renewal Charitable Trust, New Zealand. http://www.pasturerenewal.org. nz/downloads/2013_ebook.pdf

Rogers, E. M. 2003. Diffusion of innovations. 5th ed. New York: The Free Press.

Rogers, E.M.; Burdge, R.J.; Korsching, P.F.; Donnermeyr, J.F. 1988. Social change in rural societies. Englewood Cliffs, NJ: Prentice Hall.

Rumball, W. 1986. 'Grasslands Puna' chicory (Cichorium intybus L.). New Zealand Journal of Experimental Agriculture 14: 105-107.
Rumball, W.; Keogh, R.G.; Miller, J.E.; Claydon, R.B. 2003. Cultivar release 'Choice' forage chicory (Cichorium intybus L.). New Zealand Journal of Agricultural Research 46: 49-51. http://www.rsnz. govt.nz/publish/nzjar/2003/007.php

Sunding, D.; Zilberman, D. 2001. The agricultural innovation process: Research and technology adoption in a changing agricultural sector. In: Handbook of agricultural economics, Vol. 1. Eds. Gardner, B.; Rausser, G. Elsevier Science B.V.

Tapper, B.A.; Latch G.M.C. 1999. Selection against toxin production in endophyte-infected perennial rygrass. Ryegrass endophyte: An essential New Zealand symbiosis. Grasslands Research and Practice Series 7: 107-111.

Thom, E.R.; Waugh, C.D.; Minnee, E.M.K,; Waghorn, G.C. 2012. Effects of novel and wild-type endophytes in perennial ryegrass on cow health and production. New Zealand Veterinary Journal, DOI:10.1080/0048 0169.2012.715379.

Waugh, C.D.; Clark, D.A.; Harris, S.L.; Thom, E.R.; Copeman, P.J.A.; Napper, A.R. 1998. Chicory for milk production. Proceedings of the New Zealand Grassland Association 60: 33-37. 
